\title{
IAMJ
}

INTERNATIONAL

AYURVEDIC

MEDICAL JOURNAL

\section{A CLINICAL STUDY OF NASYA KARMA WITH HRISHVA-PANCHMOOL TAILA AND ABHYANGAWITH KUKKUTANDA YOGA IN THE MANAGEMENT OF MANYASTAMBHA W.S.R. TO CERVICAL SPONDYLOSIS}

\author{
Deepika Nagar ${ }^{1}$, Gyan Prakash Sharma ${ }^{2}$, Mahesh Kumar Sharma ${ }^{3}$, Preeti Swami ${ }^{4}$ \\ ${ }^{1}$ P.G. Scholar, PG Department of Panchakarma, \\ ${ }^{2}$ M.D. (Ayu). Assistant professor of Panchakarma Department, \\ ${ }^{3}$ M.D. (Ayu). Associate Professor \& Head of Panchakarma Department, \\ ${ }^{4}$ M.D. (Ayu). Assistant professor of Panchakarma Department,
}

Dr. S. R. Rajasthan Ayurved University Jodhpur, Rajasthan, India

Corresponding Author: deepsnagar31@gmail.com

\section{https://doi.org/10.46607/iamj.0709012021}

(Published online: January 2021)

Open Access

(C) International Ayurvedic Medical Journal, India 2021

Article Received: 18/12/2020 - Peer Reviewed: 22/12/2020 - Accepted for Publication: 25/12/2020

\section{Check for updates}

\begin{abstract}
Manyastambha is the clinical condition in which the back of the neck becomes stiff and the movements of the neck are hampered. Manyastambha is one of the Vatavyadhi and further explained as one of eighty types of Vataja Nanatmaja Vikara as well as Urdhwajatrugata Vikaras. It can be co-related with Cervical Spondylosis in modern medicine. Cervical Spondylosis is a degenerative condition of the cervical spine. Ruka and Stambha are the primary symptoms. If severe, it may cause pressure on nerve roots with subsequent sensory or motor disturbances. Today is the era of modernization and fast life. Everybody is busy and living stressful life. In the present observational study, housewives are more prone to develop Manyastambha (cervical spondylosis), followed by clerk, tailor, farmer. Aim- To assess the efficacy of Nasya Karma with Hrishva-Panchmool Taila and Abhyanga with Kukkutanda Yoga in the Management of Manyastambha w.s.r. to Cervical Spondylosis. Material \&Method -Present study was undertaken on 30 patients of Cervical Spondylosis. Patients diagnosed Cervical Spondylosis by X-ray and Clinical Symptoms were randomly divided into Three groups, A, B and C consisting of 10 patients in each
\end{abstract}


group. Discussion \& Conclusion- The combined therapy of Nasya and Abhyanga showed encouraging results in the subjective and objective parameters of Manyastambha. The study shows that the Kukkutanda Yoga Abhyanga and Nasya Karma with Hrishva-Panchmool Taila are very effective in the management of Manyastambha (Cervical Spondylosis). These modalities are having Vata-Kaphahara and Ushna, Snigdha Balya, Brihmna, properties are supposed to be beneficial in Manyastambha.

Keywords: Manyastambha, Cervical Spondylosis, Hrishva-Panchmool Taila, Kukkutanda Yoga, Nasya, Abhyanga

\section{INTRODUCTION}

'Manyastambha' is a Vataja Nanatmaja Vyadhi ${ }^{1}$. It is one of such lifestyle disorder which is originated from excessive use of vehicle, excessive travelling, continuous sitting and working for hours, jobs that requires heavy lifting or a lot of bending and twisting, lack of exercise, unhealthy food habits and suppression of natural urges thus are more prone to develop Manyastambha which is an emerging morbidity in the society. In the present observational study, housewives are more prone to develop Manyastambha (Cervical Spondylosis), followed by clerk, tailor, farmer. ${ }^{2}$ The main clinical features are Manyashool (Pain in nape of neck), Greevastambha (Stiffness of the neck), Greevahundana (Restricted neck movement) etc. The features of Manyastambha is generally resembles to the certain conditions of Cervical Spondylosis. The Cervical Spondylosis is one of the commonest degenerative, neurological condition by which the major population has been affected ${ }^{3}$. According to statistics, In male the prevalence is $100 \%$ by age $70 \mathrm{yrs}, 96 \%$ in women older than 70 yrs. $60-70 \%$ women and $85 \%$ of men show changes related with Cervical Spondylosis by the age $45 \mathrm{yrs} .{ }^{4}$ In some cases, the pain radiates down to the arm, hand and fingertips. This classification is made on the basis of site of pathology of cervical spine involvement. Minimal intervention shows pain confined to the neck only. Only few research projects were carried out related to the present topic. Hence there is paucity of data and least literature available for the management of Manyastambha. The particular alignment has become a challenge for health care providers. In Ayurveda, Hrishva-Panchmool Taila ${ }^{5}$ is affirmed in Charak Chikitsasthan Vatavydhi and Kukkutanda $Y_{o g} a^{6}$ is affirmed in Bhavaprakash Vatavydhi chapter in respective to management of Manyastambha Chikitsa. These modalities are having Vata-Kaphahara properties and Ushna, Snigdha, Balya and Brihmna. Which causes pacifies the Vata and Kapha through Snigdha and Ushna property and strengthen to nerve. It is theoretical view and need to be evaluated in clinical trial. Hence the research was undertaken to evaluate the efficacy of Hrishva-Panchmool Taila \& Kukkutanda Yoga in Manyastambha.

\section{Epidemiology: -}

Evidence of Spondylotic change is frequently found in many asymptomatic adults, with evidence of some disc degeneration in:

- $\quad 25 \%$ of adults under the age of 40 ,

- $\quad 50 \%$ of adults over the age of 40 and

- $\quad 85 \%$ of adults over the age of 60 showing some evidence of some disc degeneration.

Another study of Asymptomatic adults showed significant degenerative changes at one or more levels in $70 \%$ of women and $95 \%$ of men at age 65 and 60 were affected. ${ }^{7}$

Aetiology \& Pathogenesis: - Manyastambha is VataVyadhi so the Vata Vyadhi Nidana to be considered in general. But specific etiological factors described are Divaswapana (day sleep), Urdwanireekshana (looking upwards continuously), Asanasthana Vikruti (improper position during sleep). Divaswapana increases Kapha, Vikruth Asansthana \& Urdwanireekshana causes Vata vitiations. Vata \& Kapha both gets vitiated and Kaphavaranvata causes Manyasthambha. As per Vata Vyadhi no Poorvaroopa of Manyastambha are mentioned in samhitas $^{\mathbf{8}}$. Various etiological factors cause Vata vitiation and Kaphaavarana to Vata and leads to Sthanasamsraya in Manyapradesh resulting 
Dhatukshaya in Greevasandhi (neck joints) resulting in painful and restricted cervical movements.

\section{Aim \& Objectives}

1. To evaluate the therapeutic efficacy of HrishvaPanchmool Taila Nasya in Manya -stambha.

2. To evaluate the therapeutic efficacy of Kukkutanda Yoga Abhyanga in Manyastambha.

3. To evaluate the combined therapeutic effect of Hrishva-Panchmool Taila Nasya and Abhyanga With Kukkutanda Yoga in Manyastambha.

4. To establish better treatment for Manyastambha. Materials and Method:

IEC Clearance: - Approval from IEC was taken before starting the clinical trial Written consent

was taken from patients after providing them the details of the clinical trial. Source of Data:- Patients suffering from were selected from O.P.D. \& I.P.D. Department of Panchakarma, DSRRAU, Jodhpur Study Design:- Interventional Clinical study. Sample Size: 30 Patients

\section{Inclusion Criteria: -}

1. Patients suffering from classical signs and symptoms of Manyastambha vis-a-vis Cervical Spondylosis.

2. Patients between 18 yrs. to 70 yrs. of age.

3. Patients irrespective of sex, religion and socioeconomic status.

4. Patient willing and able to participate in the study for 14 days.

Exclusion Criteria:

Patients suffering from any acute diseases / Infectious diseases / Metabolic diseases / Chronic diseases (like Rheumatoid Arthritis, DM, Gout, TB, SLE, Ankylosing spondylitis etc), Patients with major systemic disorders that may interfere with the course of treatment., Stenosis of Spinal Canal, Myelopathy., Pregnant Women's ., Patients who were unfit for Nasya Karma, and Abhyanga, Recent cervical, spinal, or spinal, or shoulder surgery or implanted instrumentation or previous surgery for cervical spondylotic myelopathy.

- Grouping:

- Group A: Nasya for 14 consecutive days duration.
- Group B: Local Abhyanga will be administrated for a period of 15-20 minutes for 14 days consecutive days duration.

- Group C: Nasya Karma \& Abhyanga for 14 consecutive days.

Treatment plan: Procedure of applying HrishvaPanchmool Taila Nasya \& Kukkutanda Yoga Abhyanga.

Ingredients for Nasya

- $\quad$ Tila Taila for Local Abhyanga

- Hrishva-Panchmool Taila

Ingredients for Kukkutanda Yoga :-

- $\quad$ White part of the egg

- Go-Ghrita

- Saindhava Lavana

Instruments

- Cotton cloth - 2 meter length, 2 meter width

- Nasya Table

- induction or stove

- Frying pan, small bowl, spoon

- Sitting chair for patient

Nasya Karma:- Nasya Karma refers to administration of medicine in various forms through Nostril. It is one of Panchakarma treatment methodology of Ayurveda that's mainly indicated for Urdhvajatrugata Vikaras. It is also known as "Sirovirechana" i.e. purification through nose. It pacifies Vata and Kapha Dosha present in head region.

\section{Method of Nasya Karma:}

They were given following instruction.

$>$ To take bath with warm water 2 to 3 hours earlier to Nasya Karma and do not to take head bath daily.

$>$ To avoid suppression of natural urges.

$>$ Light breakfast half an hour before the Nasya Karma and other regimen for Nasya

mentioned in text was also advised to the patients. The procedure of Nasya Karma was performed in following three divisions.

\section{A. Poorva Karma}

- Vital of Patients should be measures.

- The room having sufficient daylight and avoid of direct atmospheric Influences like dust wind was selected. 
- Drugs and instruments required for Snehana, Swedana and Nasya were collected.

- The patient who was treated with Nasya karma applied lukewarm Hrishva- Panchmool Taila externally over the neck, face, ears, forehead etc and did light Abhyanga duration of 10 minutes.

- Mridu Swedana was given after covering the face with small cotton cloth.

- The Swedana procedure continued till Swedopatti (sweating) on face was observed.

\section{B. Pradhana Karma:-}

- After completion of Poorva karma, patient was asked to lie on table in supine position after that patient's head lowered $45^{\circ}$ angles from edge of the table.

- The limbs were kept spread apart on both sides. The foot portion of the table was slightly raised by keeping a pillow underneath.

- Patients was advised to relax with closing the eyes.

- Then Hrishva- Panchmool Taila was warmed by keeping it in hot water. With the help of thumb of the left hand raised the tip of patient's nose and with the right hand the 6 drops Hrishva-Panchmool Taila administered into each nostril.

- Patient was asked to inhale it slightly.

- Then asked the patient to expel the phlegm.

C. Pashchat Karma:-

- After Pradhana Karma patient was asked to lie in supine position.

- Panitapa Swedna was given on face. Then forehead, frontal, maxillary and temporal areas were massaged.

- Patient was advised to spit out the secretion.

- Patient was advised to take rest for 1-2 minutes in supine position.

- Then for expel the remaining Kapha Dhumpana was done.

- After completion of Dhumpana Gandusha with lukewarm water was done.

- Then after some instruction was given to patients neither to have food nor to come in contact with direct air on face and not to do cold water face wash.; within half an hour limit after Nasya Karma.

\section{Method of Abhyanga:-}

The unctuous substances used in Abhyanga therapy are for the purpose of producing lubrication, anointing or oleating effect on the internal as well as external organs. This treatment has qualities like restfulness, strength, invigoration, cognition and becomes charming and least affected by old age. This is mainly done with substances like Taila and Ghrita. The Vasa and Majja are rarely used now a days.

Preparation of Kukkutanda Yoga: White part of egg (20 ml) mixed it with equal quantity of plain cows' ghee and 1 pinch of Saindava Lavana was added. Stirred well and heated indirectly.

Time - 20-minute, Duration - 14 day

Vital of Patients should be measures. The patient was asked to attend his natural urges prior to entry in the Panchakarma theatre. The patient was asked to sit on a chair comfortably. The Kukkutanda Yoga was applied to the neck and massage was carried out for 1520 minutes. Palm was placed on two sides of the neck. With the palm in this place thumbs are approximated at the midline of the spine. Then the thumbs are simultaneously moved upward along the spine towards occiput. While moving the thumbs adequate pressure is applied on the spine. Lateral side of the neck was also massaged in sitting upright position of the patient. Facing the patients back, stand at the back. In this position palms placed on the side of the patient head on either side. Then the palms are moved downwards towards the shoulder on respective sides. Hand on the right side of the head is moved to the right shoulder. Similarly, hand on the left side of the hand is moved to left shoulder. While moving the palms on the neck should apply firm pressure. Also, at the shoulder, palms are moved in circular fashion. Fixing the duration: The duration of procedure was fixed 45minutes for 7 days. After the procedure, the patient was advised to take rest for 15-20 minutes and to wash the area with hot water.

Investigation: Routine - CBC, ESR, RBS, Specific Serum uric acid, Serum creatinine, RA factor, CRP, Xray of Cervical spine (AP \& Lat. View) 
Table 1: Assessment parameters

\begin{tabular}{|c|c|c|c|}
\hline S.No. & Parameters & Grading & Observation \\
\hline \multirow[t]{5}{*}{1} & \multirow{5}{*}{$\begin{array}{l}\text { Manyashool } \\
\text { (Pain in neck) }\end{array}$} & 0 & No pain \\
\hline & & 1 & Pain in neck, Mild aggravates with movement \\
\hline & & 2 & Pain in neck, severe aggravates with movement \\
\hline & & 3 & Pain Mild or severe with radiation to arm \\
\hline & & 4 & Pain in neck, radiation and disturbed the sleep \\
\hline \multirow[t]{5}{*}{2} & \multirow[t]{5}{*}{ Neck Stiffness } & 0 & No stiffness \\
\hline & & 1 & Stiffness, no medication \\
\hline & & 2 & Stiffness, relived by external Application \\
\hline & & 3 & Stiffness, relived by medication \\
\hline & & 4 & Stiffness, is not responded by medicine \\
\hline \multirow[t]{5}{*}{3} & \multirow[t]{5}{*}{ Restricted neck movement } & 0 & Normal neck movement \\
\hline & & 1 & Mild restriction in neck movement \\
\hline & & 2 & Moderate restriction in neck movement \\
\hline & & 3 & Severe restriction in neck movement \\
\hline & & 4 & Unbearable to move neck \\
\hline \multirow[t]{5}{*}{4} & \multirow[t]{5}{*}{ Headache } & 0 & No Headache \\
\hline & & 1 & Mild Headache Occasionally \\
\hline & & 2 & Headache once in a week \\
\hline & & 3 & Headache More than 5 times in a week \\
\hline & & 4 & Daily severe Headache \\
\hline \multirow[t]{5}{*}{5} & \multirow[t]{5}{*}{ Vertigo } & 0 & No vertigo \\
\hline & & 1 & Vertigo up to $1 \mathrm{hr}$ \\
\hline & & 2 & Vertigo up to $2 \mathrm{hr}$ \\
\hline & & 3 & Vertigo up to $3 \mathrm{hr}$ \\
\hline & & 4 & Vertigo up to more than $3 \mathrm{hr}$ \\
\hline
\end{tabular}

Radiographic Grading of Cervical Disc Degeneration by Gore et al

Grade 0- No disc space narrowing, no end plate sclerosis, and no osteophyte formation.

Grade 1- 25\% decrease in disc space narrowing, with barely visible end plate sclerosis and osteophyte formation.

Grade 2- 50\% decrease in disc space narrowing with moderate end-plate sclerosis and a moderate size osteophyte formation.

Grade 3- 75\%-disc space narrowing, severe end-plate sclerosis, and large osteophyte formation.

\section{OBSERVATIONS}

\section{Observation of demographic data}

The following were the observations of the study. Total 30 patients, 10 in each group A, B and C were registered. Maximum incidence was in the age group 41-
50 years, Male sex, Hindu religion, Married, Urban Area, Middle class, Vegetarian dietary habit, Graduate educated patients. Majority of the patients i.e.53.33\% were having Krura Koshtha and 33.33\% were having Vishamaagni, Maximum number of patient's i.e. 1-2 years chronicity, $83.33 \%$ patients had no Family history of Cervical Spondylosis. $66.67 \%$ were having gradual onset, $83.33 \%$ had No history of trauma on head or neck. Maximum number of patient's i.e.63.33\% were having Vata-Kaphaja Sharirika Prakurti, 70\% patients were having Madhyama Saara, $53.33 \%$ patients were having, Madhyama Samhanana, $66.67 \%$ patients were having Satva, 53.33\% patients have Madhyama Satmya, 50\% patients have Madhyama Vyayama Shakti. 
Observation of Subjective and Objective parameter: Out of 30 patients maximum i.e.45patients $(100 \%)$ were presented with the symptoms of Manyashool, 28 patients (87\%) were presented with the symptoms of Stambha (Stiffness In Neck), 25 patients (83\%) were presented with the symptoms of Greevahunnda (Restricted Neck Movement) and followed by Pain In Medial Scapular Region Or Arm, and 22 patients $(73 \%)$ were suffering from Headache, and 18 patients $(60 \%)$ were suffering from vertigo. It reveals that Neck pain and stiffness along with other complaints which described as main symptoms of Manyastambha and Cervical Spondylosis were observed in all patients of this series. In X-Ray findings reduction of space between $\mathrm{C}_{2}-\mathrm{C}_{3}$ Vertebra found in $6.67 \%$ patients whereas space between $\mathrm{C}_{3}-\mathrm{C}_{4}$ was diminished in $10 \%$ patients, space between $\mathrm{C}_{4}-\mathrm{C}_{5}$ was diminished in $13.33 \%$ patients, space between $\mathrm{C}_{5}-\mathrm{C}_{6}$ vertebrae was diminished in $33.33 \%$ patients, space between $\mathrm{C}_{6}-\mathrm{C}_{7}$ vertebrae was diminished $16.67 \%$ patients Reduction of space between all vertebrae was found in $20 \%$ patients. Presence of Osteophyte was found in $56.67 \%$ of patients and degenerative changes was found in $40 \%$ of patients. Abnormal cervical spine lordosis was found in $40 \%$ of patients. No side-effects were found in any patients during the course of therapy. All the patients tolerated Panchakarma procedures very well.

\section{RESULTS}

Table 2: Effect of Therapy on The Subjective Parameters in the 30 Patients of Manyastambha.

\begin{tabular}{|c|c|c|c|c|c|c|c|c|c|}
\hline \multirow{2}{*}{ Sign \& symptoms } & \multirow{2}{*}{ Gr. } & \multicolumn{2}{|c|}{ Mean score } & \multirow{2}{*}{ Difference } & \multirow{2}{*}{$\begin{array}{l}\% \\
\text { Relief }\end{array}$} & \multirow{2}{*}{ S.D \pm} & \multirow{2}{*}{$\mathrm{S} . \mathrm{E} \pm$} & \multirow{2}{*}{$\mathrm{P}$ value } & \multirow{2}{*}{$\mathrm{S}$} \\
\hline & & BT & AT & & & & & & \\
\hline \multirow{3}{*}{$\begin{array}{l}\text { Manyashool } \\
\text { (Neck Pain) }\end{array}$} & $\mathrm{A}$ & 2.500 & 1.400 & 1.100 & 44.00 & 0.5676 & 0.1795 & 0.0020 & V.S \\
\hline & B & 2.900 & 0.900 & 2.000 & 68.97 & 0.6667 & 0.2108 & 0.0010 & E.S \\
\hline & $\mathrm{C}$ & 3.200 & 0.500 & 2.700 & 84.38 & 0.6749 & 0.2134 & 0.0010 & E.S. \\
\hline \multirow{3}{*}{$\begin{array}{l}\text { Neck } \\
\text { Stiffness }\end{array}$} & A & 1.600 & 0.900 & 0.700 & 43.75 & 0.4830 & 0.1528 & 0.0078 & V.S \\
\hline & $\mathrm{B}$ & 2.000 & 0.700 & 1.300 & 65.00 & 0.6749 & 0.2134 & 0.0020 & V.S \\
\hline & $\mathrm{C}$ & 2.600 & 0.500 & 2.100 & 80.77 & 0.5676 & 0.1795 & 0.0010 & ES \\
\hline \multirow{3}{*}{ Restricted Neck movement } & A & 1.300 & 0.800 & 0.500 & 38.46 & 0.5270 & 0.1667 & 0.0313 & $\mathrm{~S}$ \\
\hline & B & 1.200 & 0.500 & 0.700 & 58.33 & 0.6749 & 0.2134 & 0.0156 & $\mathrm{~S}$ \\
\hline & $\mathrm{C}$ & 2.000 & 0.600 & 1.400 & 70.00 & 0.6992 & 0.2211 & 0.0020 & VS \\
\hline \multirow{3}{*}{ Headache } & A & 0.900 & 0.400 & 0.500 & 55.56 & 0.5270 & 0.1667 & 0.0313 & $\mathrm{~S}$ \\
\hline & B & 1.200 & 0.700 & 0.500 & 41.67 & 0.7071 & 0.2236 & 0.0625 & NQS \\
\hline & $\mathrm{C}$ & 1.200 & 0.400 & 0.800 & 66.67 & 0.6325 & 0.2000 & 0.0078 & VS \\
\hline \multirow{3}{*}{ Vertigo } & A & 1.100 & 0.600 & 0.500 & 45.45 & 0.5270 & 0.1667 & 0.0313 & $\mathrm{~S}$ \\
\hline & B & 1.000 & 0.600 & 0.400 & 40.00 & 0.5164 & 0.1633 & 0.0625 & NQS \\
\hline & $\mathrm{C}$ & 1.100 & 0.500 & 0.600 & 54.55 & 0.5164 & 0.1633 & 0.0156 & $\mathrm{~S}$ \\
\hline
\end{tabular}

Table 3: Effect of therapy on the objective parameter X-Ray in the 30 patients of Manyastambha.

\begin{tabular}{|c|c|c|c|c|c|c|c|c|c|}
\hline \multirow[t]{2}{*}{ Variables } & \multirow{2}{*}{$\begin{array}{l}\text { G } \\
\text { r. }\end{array}$} & \multicolumn{2}{|c|}{ Mean score } & \multirow{2}{*}{$\begin{array}{l}\text { Differ- } \\
\text { ence }\end{array}$} & \multirow{2}{*}{$\begin{array}{l}\% \\
\text { Relief }\end{array}$} & \multirow[t]{2}{*}{ S.D \pm} & \multirow[t]{2}{*}{ S.E \pm} & \multirow[t]{2}{*}{$P$ value } & \multirow[t]{2}{*}{ Result } \\
\hline & & B.T. & A.T. & & & & & & \\
\hline \multirow[t]{3}{*}{ X-Ray } & A & 2.100 & 1.900 & 0.200 & 9.52 & 0.4216 & 0.1333 & 0.2500 & NS \\
\hline & B & 2.200 & 1.600 & 0.600 & 27.27 & 0.5164 & 0.1633 & 0.0156 & $\mathrm{~S}$ \\
\hline & $\mathrm{C}$ & 2.300 & 1.500 & 0.800 & 34.78 & 0.4216 & 0.1333 & 0.0039 & VS \\
\hline
\end{tabular}




\section{DISCUSSION}

According to Ayurveda, treatment is 'Vighatana of Samprapti'. Manyastambha is a Vatavyadhi by its nature. It is also an inflammatory and degenerative in origin and Urdhwajatrugata Vikara. Vata is vitiated either by Avarana or Dhatukshaya. When Vata covered by Kapha or Dosha accumulation leads to Manyastambha. In initial stage of disease is Kapha Anubandanum. So, keeping in view specific treatment was evolved to pacify the Vata Dosha and reduce the Dhatukshaya. Thus, for the present study, Nasya Karma and Abhyanga was selected. The reason behind selection of Abhyanga is symptoms Manyastambha of like stiffness, pain etc. manifest through muscles, can be relieved by the local application of Abhyanga. According to Acharya Susruta Chikitsa Sthana 5/20 Vata Shlesmahara Nasya is treatment for Manyastambha. On the basis of way Nasya Karma can be best adopted to treat Manyastambha w.s.r Cervical spondylosis. Nasya Karma with Hrishva-Panchmool Taila and Abhyanga with Kukkutanda Yoga has been selected for the present study.

\section{Probable mode of action of Kukkutanda Yoga}

The contents of Kukkutanda Abhyanga are white yolk, Ghrita, and Saindava. All the contents of yoga are having Vata and Kaphahara and Balya properties which are useful in Manyastambha. Kukkutanda yoga is mentioned in Bhavaprakasha, especially indicated in Manyastambha. Here the nourishing effect will be in from the ingredients, the main ingredient being egg yolk that contains proteins and fat soluble vitamins A, $\mathrm{D}, \mathrm{E}, \mathrm{K}$ and lecithin which his present in egg yolk is having cosmetic and pharmacological application and that is how this treatment helps in nourishing skin and as acts on various pathological conditions. Kukkutanda (eggs) which are from authentic source for the procedure, so that to avoid any kind of complications and to give the optimal results. The mode of action of KukkutandaYoga Abhyanga depends on its contents. Properties of these contents are Saindhava, it has Tridoshaghna 9 , Kaphavilayan \& Kaphachedan properties. Ghrita, it pacifies Vata and acts as a rejuvenator and also Yogavahi which is helpful in increasing bioavailability of drugs. The Gunas of Sneha also play important role in absorption of the Oushadhas. Sneha Dravya has Drava, Sara, Snigdha, Picchila, Guru, Sheeta, Mrudhu and Manda Guna predominantly. The Vata Dosha, which is the key factor in the causation of diseases, has almost opposite quality to this. One unique advantage Oushadhiyukta Sneha is that their healing properties are absorbed. Oils are the rich source of lipids and having anabolic activity can account for the nourishment of underlying structures. Cell membrane act as a barrier to the passage of watersoluble molecules but provide free passage to lipid and lipid soluble substances. Kukkutanda, it is UshnaSingdha ${ }^{\mathbf{1 0}}$ in Guna which are antagonists to Gunas of Vata thus pacifies the Vata dosha. It improves the strength of fibrous tissue increases movement and flexibility of the joints and relives the pain and stiffness. Kukkatanda also helps to strengthen the nerves and relieves nerve compression.

\section{Absorption of medicine through skin}

Bhrajakapitta, one among the Panchavidhapittas, is located in the Twak. It is this Bhrajakapitta that takes up and metabolizes the drugs applied in the form of Abhyanga. After undergoing Paka, the Veerya of the medicine is absorbed through Romakupa. Then this Veerya enters into the Teeryakgata Dhamanis which are attached to Romakupa. Afterwards it starts circulating in the body through Dhamanis and enters the Dhatus one after the other in the stipulated time. It takes 800 Matrakala to enter Asthidhatu and 900 Matrakala to enter into Majjadhatu. ${ }^{11}$ The primary barrier for absorption of exogenous substances through the skin is stratum corneum. But once the drug reaches the underlying tissues it will be absorbed into the circulation. Drugs in oils and other lipid- soluble carriers can penetrate the epidermis. The movement is slow, particularly through the layers of cell membranes in the stratum corneum. Placing a drug in a solvent that is lipid soluble can assist its movement through the lipid barriers.

\section{Probable Mode of Action of Hrishva-Panchmool Taila}

This oil is preparation, prepared by Gokshur, Brihati, Kanatakari, Shalparni, Prishinaparni, Tilpinyaka, Cow-milk, Tila Taila. Among the 7 Dravyas of 
Hrishva-Panchmool Taila 2 Dravyas have VataKapha Shamak property, 3 Dravyas have Tridoshaghana property, 2 Dravyas have Vata Shamak property. Vata and Kapha both are implicated in the pathogenesis of Manyastambha hence the drug is quite effective in relieving the symptoms of Manyastambha. In the view of knowledge of modern science, the various chemicals present in components of HrishvaPanchmool Taila possess Anti-inflammatory, analgesic and strengthen to nerve etc action. Therefore, by the action of these constituents it breaks the basic pathology and help in relieving its clinical features. Tila Taila has Vatashamak, shodhana, Sandhaniya, Vedanasthapan \& Balya property. Tila Taila's property of Madhura Rasa and Vipaka, Balya, and Rasayana in Karma, it nourishes and strengthens all the Dhatus. Snigdha, Guru Guna, decrease Rukshata of Vata and Ushna Guna and Veerya helps suppress to alleviated Vata Dosha, the Vikasi Guna reduces the spasms. Being, Yogavahi nature it is Tridosha Shamak with the combination of other Dravyas. Manyastambha is a degenerative disorder so Balya property enhance the Dhatu production. Gokshur ${ }^{12}$ :- Guru and Snigdha Guna, Vednashamka, Balya and Vatashamak property of Gokshur helps to relieves pain and gives strengthen to muscles.

- Kantakari 13:- Vata-Kapha shamak, ushan veerya, shothahara, Angmarda-prashamna property of Kantakari helps to relieves pain in Manyastambha.

- Brihati ${ }^{\mathbf{1 4}}:-$ Vata-Kapha Shamak, Ushan Veerya, Shothahara, Angmarda-Prashamna property helps to relieve pain in Manyastambha.

- Shalparni ${ }^{15}$ :- Angmarda-prashamna, Tridosha shamak, NadiBalya, Snigdha- Ushan Veerya helps to pacify Vata and Teekta rasa helps to pacify Kapha.

- Prishanaparni'16:- Angmarda-prashamna, Sandhaniya, Tridoshashamak, NadiBalya, Snigdha- ushan veerya helps to pacify Vata and Teekta rasa helps to pacify Kapha.

Overall, the drug of Hrishva-Panchmool Taila is having dominance of Vata-Kaphara Doshaghanta. Manyastambha is the disease of Vata \& Kapha Dosha dominant hence the drug having Vata-Kaphahara property showed significant effect on almost all the symptoms of Manyastambha.

\section{CONCLUSION}

Manyastambha is one of the Vatavyadhi, which is commonly found in today's practice. Lifestyle in this mechanical era is very fast. Everyone has to face mental \& physical stress. Nobody has time to spend for his own health care. Hence to obey Dinacharya \& Ritucharya is far away from them. Shift duties, excessive travelling on two wheelers, irregular dietary habits, inappropriate postures are some causes, which helps in vitiation of Vata. Considering all the above factors, it is very much clear that the Vatavyadhis are increasing. There are medical and surgical treatment approaches to treat this condition which is often associated with many adverse effects. Ayurvedic approach to the disease Manyastambha is to retard the degeneration and to strengthen the Dhatus for pacifying the Vata dosha. NasyaKarma with Hrishva-Panchmool Taila and Abhyanga with Kukkutanda Yoga has been selected for the present study. These modalities are having VataKaphahara properties and Ushna, Snigdha Balya and Brihmna. Which causes pacifies the Vata and Kapha through Snigdha and Ushna property and strengthen to muscle. Both therapies have no complication and easy to practice. Along with aforesaid therapies, postural corrections during work, sleep, travel and avoidance of elevated cushions below the neck, coupled with regular exercises can go long in preventing the Cervical Spondylosis.

\section{REFERENCES}

1. Charak Samhita Of Agnivesa Revised by Charak And Drdhabala With Elaborated Vidyotini Hindi Commentary by Pt. Kashinatha Sastri, Dr Gorakha Natha Chaturvedi Part -1, Chaukhambha Bharti Academy; 2013 Sutra Sthana shlok 20/11, Pg. 399

2. https://doi.org/10.21760/jaims.v2i1.7490

3. Rosomoff HL, Fishbain D, Rosomoff RS. Chronic cervical pain: radiculopathy or brachialgia. Non interventional treatment. Spine (Phila Pa 1976). 1992 Oct. 17(10 Suppl): S 362-6. 
4. Sandeep rana edited Medicine- Medscape' Continually updated clinical reference.

5. Charak Samhita, Charak Samhita Of Agnivesa Revised by Charak And Dradhabala With Elaborated Vidyotini Hindi Commentary by Pt. Kashinatha Sastri, Dr Gorakha Natha Chaturvedi Part -2, Chaukhambha Bharti Academy; 2013 Chikitsa Sthana Chapter 28 shlok no 138, page no. 802

6. Bhavmishra, Bhavprakash Samhita Of Bhavmishra Volume-2 With Vidyotini Hindi Commentary by Pandit Sri Brhma Shankar Mishra, Edition 2013Varanasi; Chaukhambha Sanskrit Sansthan; 2013 Madhyama Khanda Chikitsa Prakarn Chapter 24 Shlok No 76.

7. Nicholas A. Boon, Nicki R Colledge, Brian R Walker, John A. A. Hunter, Davidson's principles and practice of Medicine; $20^{\text {th }}$ Edition, Churchill Livingstone Gray's Anatomy, Elsevier; Reprinted.2008, p.1241

8. R Alagappan, Manual of Practical Medicine, Fourth Edition, Jaypee Brothers Medical Publishers; 2011, p.573

9. Charak Samhita Of Agnivesa Revised by Charak And Drdhabala With Elaborated Vidyotini

10. Hindi Commentary by Pt. Kashinatha Sastri, Dr Gorakha Natha Chaturvedi Part -1,

11. Chaukhambha Bharti Academy; 2013 Sutra Sthana shlok 27/300, Pg. 561

12. Charak Samhita Of Agnivesa Revised by Charak And Drdhabala With Elaborated Vidyotini Hindi Commentary by Pt. Kashinatha Sastri, Dr Gorakha Natha Chaturvedi Part -1, Chaukhambha Bharti Academy; 2013 Chikitsa Sthana Chapter13 shlok no 14, page no. 258

13. Acharya Priyavat Sharma edited Susrutha Samhitha Dalhana teeka Chikitsasthana 24th chapter, 30th sloka Reprint 2007.Chaukambha Orientalia. pg no.488.

14. Dr. J.L.N. Sastry, Dravyaguna Vijnana (Study of The Essential Medical Plants in Ayurveda), Chukhambha Orientali, Varanasi; Reprint; 2017, Vol-1, p. 98

15. Dr. J.L.N. Sastry, Dravyaguna Vijnana (Study of The Essential Medical Plants in Ayurveda), Chukhambha Orientalia, Varanasi; Reprint; 2017, Vol-2, P-367

16. Dr. Gyanendra Pandey, Dravyaguna Vijanana, Chowkhamba Krishnadas Academy, Varanasi; Reprint; 2004, Part -1 P. 441-446

17. Dr. J.L.N. Sastry, Dravyaguna Vijnana (Study of The Essential Medical Plants in Ayurveda), Chukhambha Orientalia, Varanasi; Reprint; 2017, Vol-1, P-160

18. Dr. Gyanendra Pandey, Dravyaguna Vijanana, Chowkhamba Krishnadas Academy, Varanasi; Reprint; 2004, Part -3 P. 168-173

\section{Source of Support: Nil Conflict of Interest: None Declared}

How to cite this URL: Deepika Nagar et al: A Clinical Study Of Nasya Karma With Hrishva-Panchmool Taila And Abhyangawith Kukkutanda Yoga In The Management Of Manyastambha W.S.R. To Cervical Spondylosis. International Ayurvedic Medical Journal \{online\} 2021 \{cited January, 2021\} Available from: http://www.iamj.in/posts/images/upload/44_52.pdf 